\title{
Study on the environmental state in Tan Rai bauxite mining area Bao Lam district, Lam Dong province
}

\author{
Nghiên cưu hiện trạng môi trương vùng khai thác mỏ bauxite Tân Rai tại huyện \\ Bảo Lâm, tỉnh Lâm Đồng
}

Research article

Pham Thi Thu Ha ${ }^{1}$, Mai The Duong ${ }^{2}$, Duong Ngoc Bach ${ }^{3}$, Nguyen Viet Hoai ${ }^{3}$, Phi Thi Ly ${ }^{3}$

${ }^{I}$ Faculty of Environmental Sciences, VNU University of Science, 334 Nguyen Trai, Thanh Xuan, Ha Noi; ${ }^{2}$ Center of Industrial Environment, National Institute of Mining - Metallurgy Science and Technology, 79 An Trach, Dong Da, Ha Noi, Vietnam; ${ }^{3}$ Research Center for Environmental Monitoring and Modeling, VNU University of Science, 334 Nguyen Trai, Thanh Xuan, Ha Noi, Vietnam

\begin{abstract}
Planting trees in mining zones for post-mining rehabilitation is of great interest. Therefore, it is important and necessary to study the current state of the air, water, and soil environment in the mine exploited area. Therefore, this article studied and assessed the environmental state in Tan Rai bauxite mining area at Bao Lam district, Lam Dong province through the environmental components of air, water and soil, as a basis for selection of suitable crops for post-mining rehabilitation. The research result showed that the air quality in the bauxite mining area met the standard 3733/2002/QĐ-BYT. Almost monitoring parameters of surface water and wastewater is within the allowed threshold of Vietnam standards. However surface water had a sign of TSS and COD pollution (TSS and COD at the Danos stream after the received point of wastewater from No.6 tailing lake were 1.6 times and 1.07 times higher than those in standard). Ground water was polluted by Coliform (20-63,3 times over standard) and cation $\mathrm{NH}_{4}^{+}$(1.1-1.5 times over standard); Soil in exploiting region was strongly impacted, soil profile has changed, red-yellow soil dominated, soil fertility is pretty high, $\mathrm{pH}_{\mathrm{H} 20}$ and $\mathrm{pH}_{\mathrm{KC}}$ were from acid to neuter. This studied environment state is very suitable for planting pine and acacia. These results will be useful references, as a basis for orientation of post-mining rehabilitation.
\end{abstract}

Việc trồng cây xanh để phục hồi các vùng mỏ sau khai thác hiện đang rất được quan tâm. Do vậy, việc nghiên cứu hiện trạng môi truờng không khí, nước và đất ở vùng khai thác mỏ là rất quan trọng và cần thiết. Bài báo nghiên cưu đánh giá hiện trạng môi truò̀ng vùng khai thác mỏ Bauxite Tân Rai, huyện Bảo Lâm, tỉnh Lâm Đồng thông qua các thành phần môi trương không khí, nước, đất, làm co sở cho việc lựa chọn loại cây trồng phù hợp cho công tác phục hồi môi trừ̀ng sau khai thác mỏ. Kết quả nghiên cưu cho thấy, chất lượng môi truờng không khí tại vùng khai thác mỏ Bauxite đạt tiêu chuẩn 3733/2002/QĐ-BYT. Hầu hết các thông số quan trắc của nước mặt và nước thải đều nằm trong giới hạn cho phép theo tiêu chuẩn Việt Nam, tuy nhiên môi truờng nước mặt cũng đang có dấu hiệu ô nhiếm TSS và COD (TSS và COD tại suối Danos phía duoói điểm tiếp nhận nước thải hồ quặng đuôi số 6 tuơng ưng gấp 1,6 lần và 1,07 lần so với tiêu chuẩn). Nuớc ngầm đang bi ô nhiếm Coliform (vuợt quy chuẩn cho phép tù 20-63,3 lần) và $\mathrm{NH}_{4}^{+}$(vượt quy chuẩn cho phép tù̀ 1,1-1,5 lần); Đất tại khu vục khai thác bị tác động mạnh mẽ, phẫu diện đất bi thay đổi, đất đỏ vàng chiếm uu thế, đất có độ phì khá, $p H_{H 2 O}$ và $p H_{K C l}$ tù chua đến trung tính. Kết quả hiện trạng môi truòng nhu vậy là phù hợp với trồng thông và keo. Nhũng kết quả này là tài liệu tham khảo hữu ích, làm cơ sở cho việc định hướng phục hồi đất sau khai thác mỏ.

Keywords: environmental state, bauxite mining, Tan Rai 


\section{Introduction}

Vietnam has a great potential for bauxite in the region and in the world. Bauxite ore is found in both the North and the South of Vietnam, but the largest concentration is in the South-Central Highlands. Total bauxite ore reserves in Vietnam are forecasted at 5.5 billion tons, of which about 91 million tons are in the North, and 5.4 billion tons are in the south [1].

Tan Rai Bauxite mine covers an area of $42 \mathrm{~km}^{2}$ in Loc Thang, Loc Phu and Loc Ngai communes in Bao Lam district, $20 \mathrm{~km}$ far from Bao Loc town in the Northeast. This mine has been licensed for exploitation under the Mineral License No. 1084 / GP-BTNMT dated 21/06/2010 of the Minister of Ministry of Natural Resources and Environment [2] with the licensed mining reserve of $119,361,000$ tons of ore, and the mining capacity of 4,318,000 tons per year. With these identified bauxite ore resources, Tan Rai Bauxite Mining Project in Bao Lam district, Lam Dong province plays a very important role in the economy and industrialization of the country. However, the exploitation of bauxite ore can adversely affect the environment of soil, water, air and organisms, especially the soil environment. Mine soil will be eroded very quickly, the fertility of soil will be decreased if it is not covered or planted by forest. Surface water may be polluted by the increase of suspended solids, acid content and turbidity. Deforested areas will lose their landscape, negatively affecting human vision: dust, mechanical noise and explosives can disrupt the ambient environment, affecting the health of the surrounding population $[2,6]$.

Impact of bauxite mine was investigated in some previous studies $[19,20,21]$. These studies were carried out to evaluate the environmental effect of bauxite mine activities on the ecology, benthic foraminifer from two sides along the Cassidaigne Canyon [19, 20]. However, there were rare studies on assessment of environmental state in bauxite mine area for the purpose of post-mine rehabilitation.

Rehabilitation of the post-mining environment is of great interest. Currently, the selected improvement plan for post-mining rehabilitation is often planting trees in mining zones right after mine exploitation. Therefore, in order to be able to select plants suitable for the environment in mining area, it is important and necessary to study the current state of the air, water, and soil environment in the mine exploited area, as a basis for the selection of suitable crops under the environmental conditions that have been changed by bauxite mining activities.

Due to the above issues, the study on the environmental state in the exploitation process at Tan Rai Bauxite mine Bao Lam - Lam Dong is very necessary, as a basis for orienting the post - mine rehabilitation.

\section{Research objectives, scope and methods}

\subsection{Research objectives and scope}

- Overall research objective: Study on the status of air, water and soil environment in Tan Rai Bauxite mining area, as a basis for selection of suitable crops for postmining rehabilitation. In order to realize this objective the air, water and soil in the Tan Rai Bauxite mining area were collected and investigated. Base on the result obtained we will select suitable plants for post-mining rehabilitation.

- Research scope: Tan Rai Bauxite mining area in three communes: Loc Thang, Loc Phu, Loc Ngai in Bao Lam district, Lam Dong province from March to September 2017.There are some activities in the mine area which included: preparing mining operations (cutting trees, constructing roads), exploiting bauxite ore, transporting ore to the refinery and transporting waste soil to the dumping area. In the un-exploited areas, the status remains the same as in the beginning, where there is still the cultivation of the population, mainly the cultivation of forest trees such as coffee, cashew, pine, tea. Rehabilitation, backfill and green cover by planting trees for the areas that have been exploited was done after the discharge and soil fill activities.

\subsection{Methods}

\subsubsection{Field survey and sampling method}

In order to carry out an assessment of the environmental status at Tan Bauxite mine, the study implemented the field survey, on-site monitoring and taking the air and surface water samples at the Tan Rai Bauxite mine site for laboratory analysis. Data on groundwater, wastewater and soil were taken from the monitoring reports of the study area.

The survey was conducted in 02 phases: 1st round on June 08-12th, 2017 and 2nd round on September 21-23rd, 2017. These selected environmental sampling points were affected by current and future mining activities, such as exploitation areas, transport areas, unexploited areas, discharge area, and affected residential areas.

Methods of sampling and preservation were implemented in accordance with the guidelines in the current regulations of Vietnam. All the methods in the guidelines are standard analytical methods which were carefully tested.

- For air samples: The methods of measuring temperature, humidity and wind speed were carried out in accordance with guidelines in QCVN 46: 2012/BTNMT [7]; noise, $\mathrm{SO}_{2}, \mathrm{NO}_{2}$, TSS in accordance with TCVN 7878-2:2010 [8], TCVN 5971:1995 [9], TCVN 6137:2009 [10], and TCVN 5067:1995 [11], respectively.

- Sampling and preservation of water samples were carried out according to the methods specified in TCVN 
6663-1:2011 [12], TCVN 6663-3:2008 [13], TCVN $6663-$ 6:2008 [14], TCVN 5994-1995 [15]; method for $\mathrm{pH}$ was according to TCVN 6492:2011 [16].

\subsubsection{Analytical methods in the laboratory}

The samples that could not rapidly measured in the field were stored and analyzed in the laboratory. Methods of analysis are performed in accordance with TCVN 6625:2000, TCVN 6626:2000, TCVN 6658:2000, TCVN 7877:2008, TCVN 6177:1996, SMEWW 3113B:2012, SMEWW 5520B:2012, SMEWW 2540C:2012 [17].

\subsubsection{Method of data process}

After collecting, measuring and analyzing the environmental samples, data was processed using Microsoft Excel 2010 software in order to assess the environmental state in the study area, as a basis for the environmental rehabilitation and restoration after mining for Tan Rai Bauxite mine.

\section{Results and discussion}

\subsection{Air environmental state}

The major sources of air pollution in the Tan Rai Bauxite mine include mining operation activities such as drilling, blasting, unloading, machinery and equipment using diesel fuel and from material transportation activities. Therefore, in order to assess the effects of mine activities on air environment, several typical air parameters for mining such as suspended dust, $\mathrm{SO}_{2}, \mathrm{CO}, \mathrm{NO}_{2}$, and some microclimate parameters were selected.

The survey and monitoring results of four air samples (see the sampling locations in Figure 1) are shown in Table 1. In general, all the parameters at the monitoring points are within the thresholds stipulated in Decision $3733 / 2002 / \mathrm{QD}-\mathrm{BYT}$ on the promulgation of 21 labor sanitation standards, 05 principles and 07 labor sanitation parameters.

Table 1. Monitoring result of air environmental status

\begin{tabular}{|c|c|c|c|c|c|c|c|c|c|}
\hline Sampling locations & $\begin{array}{c}\text { Sampling } \\
\text { time }\end{array}$ & $\begin{array}{c}\text { Temperature } \\
\left({ }^{\circ} \mathrm{C}\right)\end{array}$ & $\begin{array}{c}\text { Humidity } \\
\text { (\%) }\end{array}$ & $\begin{array}{l}\text { Wind } \\
\text { speed } \\
(\mathrm{m} / \mathrm{s})\end{array}$ & $\begin{array}{l}\text { Noise } \\
\text { (dBA) }\end{array}$ & $\underset{\left(\mu \mathrm{g} / \mathrm{m}^{3}\right)}{\mathrm{SO}_{2}}$ & $\underset{\left(\mu \mathrm{g} / \mathrm{m}^{3}\right)}{\mathrm{CO}}$ & $\underset{\left(\mu \mathrm{g} / \mathrm{m}^{3}\right)}{\mathrm{NO}_{2}}$ & $\begin{array}{c}\text { Suspended } \\
\text { dust } \\
\left(\mu \mathrm{g} / \mathrm{m}^{3}\right)\end{array}$ \\
\hline \multirow{2}{*}{ Exploiting area (K1) } & Phase 1 & 25.8 & 78.6 & 1.2 & 74.5 & 44 & 4,200 & 34 & 550 \\
\hline & Phase 2 & 22.6 & 87.4 & 1.1 & 72.4 & 43 & 4,100 & 33 & 518 \\
\hline \multirow{2}{*}{$\begin{array}{l}\text { Area of dumping soil } \\
\text { after mining (K2) }\end{array}$} & Phase 1 & 25.6 & 76.4 & 1.3 & 69.4 & 36 & 3,900 & 21 & 289 \\
\hline & Phase 2 & 22.8 & 83.5 & 0.9 & 68.2 & 37 & 3,700 & 24 & 266 \\
\hline \multirow{2}{*}{$\begin{array}{l}\text { Area of ore transport } \\
\text { route }(\mathrm{K} 3)\end{array}$} & Phase 1 & 26.1 & 77.8 & 1.4 & 71.1 & 42 & 4,400 & 36 & 820 \\
\hline & Phase 2 & 22.4 & 84.5 & 1.2 & 72.8 & 43 & 4,300 & 35 & 801 \\
\hline \multirow{2}{*}{$\begin{array}{l}\text { Unexploited } \\
\text { (K4) }\end{array}$} & Phase 1 & 25.2 & 80.5 & 0.8 & 55.4 & 35 & 3,500 & 20 & 170 \\
\hline & Phase 2 & 21.9 & 90.4 & 0.7 & 55.7 & 32 & 3,500 & 19 & 165 \\
\hline $\begin{array}{l}\text { Decision 3733/2002/QD- } \\
\text { BYT (Maximum times) }\end{array}$ & & - & - & - & 85 & 10,000 & 40,000 & 10,000 & 4,000 \\
\hline
\end{tabular}

Microclimate: Tan Rai Bauxite mine is characterized by the climate of southern Lam Dong province, cool weather, high relative humidity. With the above micro climatic conditions, the operation and production activities of the mine will not be affected and take place relatively smoothly.

Suspended dust and noise: Although waste rock and soil at the locations of ore mining and transportation is relatively high and higher than the location of unexploited area, the concentrations of suspended dust and noise at these sites are still within the allowable limits of the regulations.

The results of $\mathrm{SO}_{2}, \mathrm{NO}_{2}, \mathrm{CO}$ and Suspended dust at four sampling sites in two times phases are shown in Figure 2 and Figure 3. The concentrations of $\mathrm{SO}_{2}, \mathrm{NO}_{2}, \mathrm{CO}$ and Suspended dust were lower than the allowable thresholds in Decision 3733/2002/QD-BYT. The values of $\mathrm{SO}_{2}$, $\mathrm{NO}_{2}, \mathrm{CO}$ and Suspended dust were not much different between two phases. The concentrations of $\mathrm{SO}_{2}, \mathrm{NO}_{2}, \mathrm{CO}$ and Suspended dust at K1 (Exploiting area) and K3 (Area of ore transport route) were higher than at K2 (Area of dumping soil after mining) and K4 (Unexploited area). The cause of this phenomenon is due to the effects of soil digging activities for ore mining at $\mathrm{K} 1$ and of ore transporting means at $\mathrm{K} 3$.

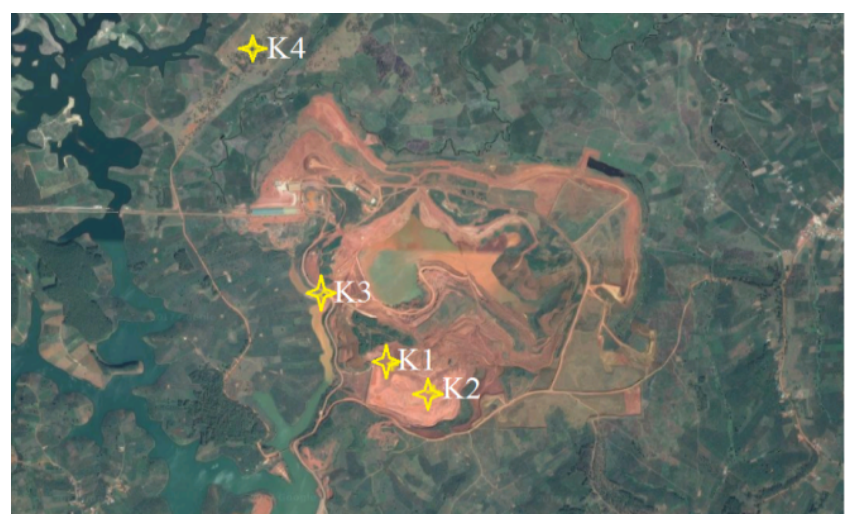

Figure 1. Locations of air monitoring points 


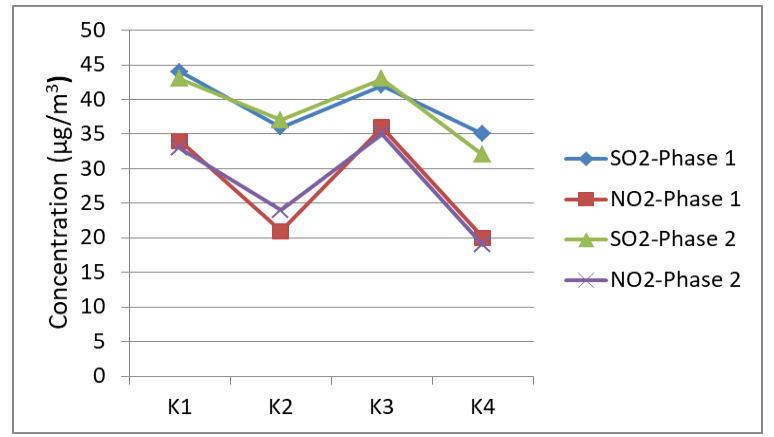

Figure 2. Results of $\mathrm{SO}_{2}, \mathrm{NO}_{2}$ concentrations

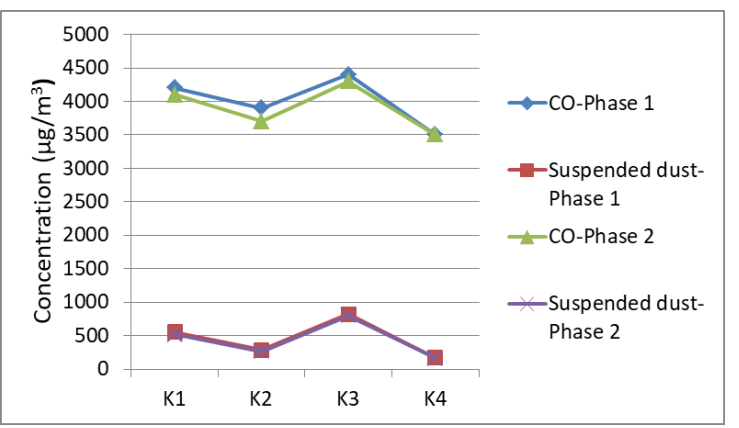

Figure 3. Results of CO and Suspended dust concentrations

\subsection{Water environmental state}

\section{- Surface water}

The mine belongs to the upstream area of Dargna River Basin, in which the Danos Stream flows across the mine. The main river systems and tributaries have formed the regional hydrological system and all flow into the Dargna River in the southwest. The water supply for the bauxitealuminum complex is taken from Dargna River by damming the reservoir on the river [4].

Surface water sampling sites at Tan Rai Bauxite mining area are shown in Figure 4, including water at Cai Bang lake (NM1), Danos Stream water at the runoff area from raw ore region of ore sifting plant (NM2), and Dagrana Stream water after Cai Bang Lake Dam (NM3). Twelve selected parameters are the typical parameters for mine activities such as $\mathrm{pH}$, TSS, heavy metals... The results of surface water quality monitoring and analysis are shown in Table 2.

The results showed that the concentrations of most parameters were within the allowable thresholds by QCVN 08-MT:2015/BTNMT (column B1). However, $\mathrm{Mn}^{2+}$ concentration at Danos Stream in phase 2 reached the allowable threshold. TSS at Danos Stream was also higher than other monitoring points. In addition, according to the monitoring data of the mine in 2015, 2016, 2017 [3], the concentrations of TSS and COD at Danos Stream after the receiving point of wastewater from the tailings sewage lake No. 6 were over the allowable thresholds in QCVN during the sampling period from $09 \div 11 / 5 / 2016,1.6$ times and 1.07 times higher than the standards for TSS and COD, respectively.
It can be said that the surface water quality in the mining area was affected by the bauxite mining activities, especially for TSS parameter.

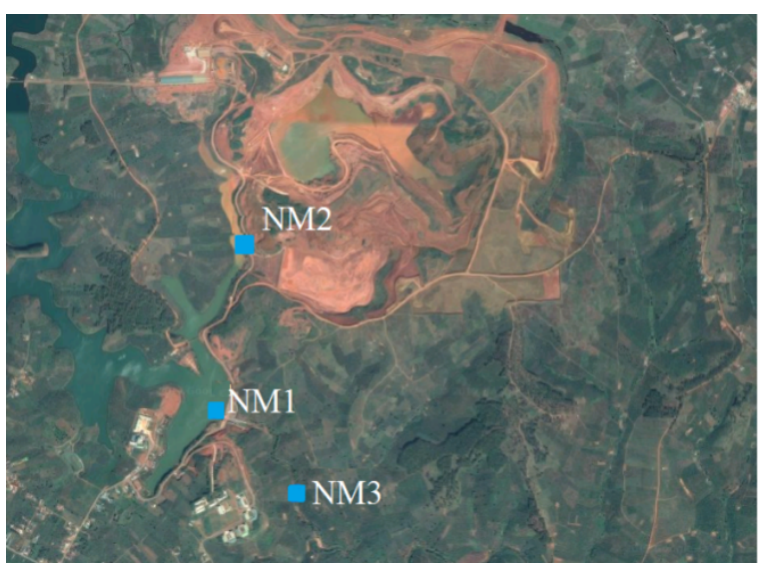

Figure4: Locations of surface water monitoring points

\section{- Underground water}

Currently, there are still people living in the ore unexploited areas, to evaluate the groundwater environment in this area, the authors used the monitoring results in 2017 conducted by VITE Company [5].

The results showed that all groundwater samples at Tan Rai Bauxite mine and surrounding areas were seriously polluted by Coliform, over the allowable standards from 20-63,3 times (Figure5). In addition, two thirds of the samples at NN3 had ammonium concentrations exceeding the standard threshold of 1.1-1.5 times. Other parameters met the standards according to QCVN MT:2015/BTNMT. The cause of Coliform and $\mathrm{NH}_{4}{ }^{+}$pollution is due to the water samples taken at wells of neighboring areas, the wells have a small depth (about 5-10m), so the water source is contaminated by sanitation and livestock activities of people.

\section{- Wastewater}

Currently, the mining area has a capacity of 4,318,000 tons/year (original bauxite ore). With the form of open mining, the mine site does not use water for mining operations. Therefore, the mining operation does not generate waste water, there are mainly rainfall overflowing on the site, rainwater flowing over internal transportation roads in the field.

The monitoring results at the output of tailings discharge reservoir No. 6 before pouring into the receiving water source in 2016 and 2017 implemented by the Center for Monitoring and Natural Resources, Environment of the Department of Natural Resources and Environment in Lam Dong province showed that the concentrations of all monitoring parameters were within the thresholds specified in QCVN 40:2011/BTNMT-National technical regulation on industrial wastewater (Table 3) [18]. 
Table 2. The analytical results of surface water at Tan Rai Bauxite mining area

\begin{tabular}{|c|c|c|c|c|c|c|c|c|c|c|c|c|c|c|}
\hline Code & Monitoring points & $\begin{array}{c}\text { Monitoring } \\
\text { phase }\end{array}$ & $\mathbf{p H}$ & $\begin{array}{c}\text { TSS } \\
(\mathrm{mg} / \mathrm{l})\end{array}$ & $\begin{array}{c}\mathrm{As} \\
(\mathrm{mg} / \mathrm{l})\end{array}$ & $\begin{array}{c}\mathrm{Cd} \\
(\mathrm{mg} / \mathrm{l})\end{array}$ & $\begin{array}{c}\mathrm{Pb} \\
(\mathrm{mg} / \mathrm{l})\end{array}$ & $\begin{array}{r}\mathrm{Cr}^{6+} \\
(\mathrm{mg} / \mathrm{l})\end{array}$ & $\underset{(\mathrm{mg} / \mathrm{l})}{\mathrm{Cu}}$ & $\begin{array}{l}\mathrm{Mn}^{2+} \\
(\mathrm{mg} / \mathrm{l})\end{array}$ & $\begin{array}{c}\text { Hg } \\
(\mathrm{mg} / \mathrm{l})\end{array}$ & $\begin{array}{c}\mathrm{Fe}_{\mathrm{tp}} \\
(\mathrm{mg} / \mathrm{l})\end{array}$ & $\begin{array}{c}\text { Oil } \\
(\mathrm{mg} / \mathrm{l})\end{array}$ & $\begin{array}{c}\text { Total } \\
\text { sediment } \\
(\mathrm{mg} / \mathrm{l}) \\
\end{array}$ \\
\hline \multirow{2}{*}{ NM1 } & \multirow{2}{*}{ Water at Cai Bang lake } & Phase 1 & 6.55 & 33 & $<0.001$ & 0.003 & $<0.001$ & $<0.002$ & 0.04 & 0.4 & 0.0006 & 0,21 & 0,5 & 79 \\
\hline & & Phase 2 & 6.53 & 29 & $<0.001$ & 0.003 & $<0.001$ & $<0.002$ & 0.05 & 0.3 & 0.0005 & 0,19 & 0,6 & 70 \\
\hline \multirow[t]{2}{*}{ NM2 } & \multirow[t]{2}{*}{$\begin{array}{l}\text { Danos Stream water at the } \\
\text { runoff area from raw ore } \\
\text { region of ore sifting plant }\end{array}$} & Phase 1 & 6.71 & 37 & $<0.001$ & 0.004 & $<0.001$ & $<0.002$ & 0.08 & 0.3 & 0.0008 & 0,13 & 0,8 & 72 \\
\hline & & Phase 2 & 6.79 & 40 & $<0.001$ & 0.004 & $<0.001$ & $<0.002$ & 0.06 & 0.5 & 0.0004 & 0,15 & 0,9 & 75 \\
\hline \multirow[t]{2}{*}{ NM3 } & \multirow{2}{*}{$\begin{array}{l}\text { Dagrana Stream water } \\
\text { after Cai Bang Lake Dam }\end{array}$} & Phase 1 & 6.82 & 30 & $<0.001$ & 0.002 & $<0.001$ & $<0.002$ & 0.05 & 0.2 & 0.0004 & 0,15 & 0,3 & 58 \\
\hline & & Phase 2 & 6.77 & 31 & $<0.001$ & 0.002 & $<0.001$ & $<0.002$ & 0.05 & 0.3 & 0.0003 & 0,12 & 0,3 & 60 \\
\hline & \multicolumn{2}{|c|}{$\begin{array}{l}\text { QCVN 08-MT:2015/BTNMT } \\
\text { (Colunm B1) }\end{array}$} & $\begin{array}{c}5.5- \\
9\end{array}$ & 50 & 0.05 & 0.01 & 0.05 & 0.04 & 0.5 & 0.5 & 0.001 & 1.5 & 1 & - \\
\hline
\end{tabular}

Table 3. The analytical results of wastewater at Tan Rai Bauxite mining area (Q1, Q2, Q3, Q4: Quarter 1,2,3,4 of the year)

\begin{tabular}{|c|c|c|c|c|c|c|c|c|}
\hline No & Parameter & Q1/2016 & Q2/2016 & Q3/2016 & Q4/2016 & Q1/2017 & Q2/2017 & QCVN 40:2011/BTNMT \\
\hline 1 & $\mathrm{pH}$ & 7.09 & 6.57 & 5.62 & 7.86 & 7.25 & 7.06 & $5.5-9$ \\
\hline 2 & Flow rate $(1 / \mathrm{s})$ & 20.1 & 0.1094 & 0.6321 & 0.1040 & 0.048 & 0.03996 & - \\
\hline 3 & TSS (mg/l) & 8 & 8 & 86 & 46 & 44 & 6 & 100 \\
\hline 4 & COD (mg/l) & 14 & 18 & $<10$ & 11 & 12 & $<10$ & 150 \\
\hline 5 & $\mathrm{BOD}_{5}(\mathbf{m g} / \mathbf{l})$ & $<3$ & $<3$ & $<3$ & $<3$ & $<3$ & $<3$ & 50 \\
\hline 6 & $\mathrm{~N}-\mathrm{NH}_{4}^{+}(\mathbf{m g} / \mathbf{l})$ & 1.32 & 0.74 & 0.7 & 1.12 & 1.43 & 0.4 & 10 \\
\hline 7 & Total N (mg/l) & 3.48 & 3.92 & 2.46 & 3.92 & 3.98 & 2.8 & 40 \\
\hline
\end{tabular}




\begin{tabular}{|c|c|c|c|c|c|c|c|c|}
\hline No & Parameter & Q1/2016 & Q2/2016 & Q3/2016 & Q4/2016 & Q1/2017 & Q2/2017 & QCVN 40:2011/BTNMT \\
\hline 8 & Total P (mg/l) & $<0.03$ & $<0.03$ & 0.09 & $<0.03$ & $<0.03$ & 0.04 & 6 \\
\hline 9 & As (mg/l) & $<0.001$ & $<0.001$ & $<0.001$ & $<0.001$ & $<0.001$ & $<0.001$ & 0.1 \\
\hline 10 & $\mathrm{Hg}(\mathbf{m g} / \mathbf{l})$ & $<0.0005$ & $<0.0005$ & $<0.0005$ & $<0.0005$ & $<0.0005$ & $<0.0005$ & 0.01 \\
\hline 11 & $\mathrm{Cu}(\mathbf{m g} / \mathbf{l})$ & $<0.1$ & $<0.1$ & $<0.1$ & $<0.1$ & $<0.1$ & $<0.1$ & 2 \\
\hline 12 & $\mathrm{Zn}(\mathbf{m g} / \mathrm{l})$ & $<0.08$ & $<0.08$ & $<0.08$ & $<0.08$ & 0.1 & $<0.08$ & 3 \\
\hline 13 & $\mathrm{~Pb}(\mathbf{m g} / \mathbf{l})$ & $<0.01$ & $<0.01$ & $<0.010$ & $<0.01$ & $<0.01$ & $<0.01$ & 0.5 \\
\hline 14 & $\mathrm{Cd}(\mathbf{m g} / \mathbf{l})$ & $<0.0005$ & $<0.0005$ & $<0.00050$ & $<0.0005$ & $<0.0005$ & $<0.0005$ & 0.1 \\
\hline 15 & $\operatorname{Mn}(\mathbf{m g} / \mathbf{l})$ & $<0.04$ & $<0.04$ & 0.222 & 0.14 & $<0.04$ & $<0.04$ & 1 \\
\hline 16 & $\mathrm{Fe}(\mathbf{m g} / \mathbf{l})$ & 0.5 & $<0.2$ & 3.19 & 2.81 & 0.53 & 0.24 & 5 \\
\hline 17 & Ni (mg/l) & $<0.010$ & $<0.010$ & $<0.010$ & $<0.010$ & $<0.01$ & $<0.01$ & 0.5 \\
\hline 18 & $\mathrm{CN}^{-}(\mathbf{m g} / \mathbf{l})$ & $<0.0020$ & $<0.0020$ & $<0.0020$ & $<0.0020$ & $<0.0020$ & $<0.0020$ & 0.1 \\
\hline 19 & Phenols (mg/l) & $<0.0040$ & $<0.0040$ & $<0.0040$ & $<0.0040$ & $<0.0040$ & $<0.0040$ & 0.5 \\
\hline 20 & Mineral oil (mg/l) & $<0.50$ & $<0.50$ & $<0.50$ & $<0.50$ & $<0.50$ & $<0.50$ & 10 \\
\hline 21 & Sunfua (mg/l) & $<0.10$ & $<0.10$ & $<0.10$ & $<0.10$ & $<0.10$ & $<0.10$ & 0.5 \\
\hline 22 & Crom (III) (mg/l) & $<0.010$ & $<0.010$ & 0.022 & 0.014 & 0.022 & 0.022 & 1 \\
\hline 23 & Crom (VI) (mg/l) & $<0.010$ & $<0.010$ & $<0.010$ & $<0.010$ & $<0.010$ & $<0.010$ & 0.1 \\
\hline 24 & $\begin{array}{l}\text { Total radioactive } \\
\alpha(\mathrm{Bq} / \mathrm{L})\end{array}$ & $\mathrm{KPH}$ & $\mathrm{KPH}$ & $\mathrm{KPH}$ & $\mathrm{KPH}$ & $\mathrm{KPH}$ & $\mathrm{KPH}$ & 0.1 \\
\hline 25 & $\begin{array}{l}\text { Total radioactive } \\
\beta(\mathrm{Bq} / \mathrm{L})\end{array}$ & $\mathrm{KPH}$ & $\mathrm{KPH}$ & $\mathrm{KPH}$ & $\mathrm{KPH}$ & $\mathrm{KPH}$ & $\mathrm{KPH}$ & 1 \\
\hline 26 & $\begin{array}{l}\text { Coliform } \\
/ 100 \mathrm{~mL})\end{array}$ & 790 & $<3$ & $<3$ & 930 & 91 & 230 & 5000 \\
\hline
\end{tabular}




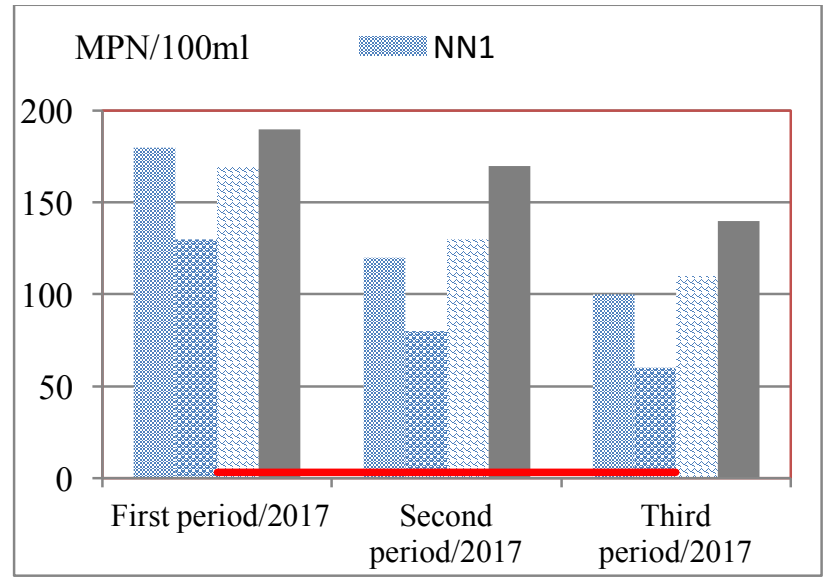

Figure 5: Coliform concentrations in groundwater samples at the area of Tan Rai Bauxite mine in 2017

Note: - NN1: Water of digging well at No.15 residential area, Loc Thang town - NN2: Water of digging well at the project management board of Lam Dong bauxitealuminum complex.

- NN3: Water of digging well at No.11Village of Loc Ngai commune.

- NN4: Water of digging well at the collective quarter of mine workers.

\section{Soil environmental state}

In the process of exploiting bauxite, the Laterit-Bauxite and Bauxite-Laterite layers which are rich in minerals have been fully exploited, so there remains only layers of cover soil, litoma, weathered bazan and fresh bazan. The cover soil was totally disturbed, the structure of the soil layer was affected, thethickness of recovery soil layer was $0.5-1 \mathrm{~m}$, the texture of the soil was slightly tight,the soil porosity is from moderate to fairly good;

Litoma layeris widely distributed throughout the mine and located near the bottom of the Bauxite ore layer. The soil in this layer is brown, brownish-yellowish and has many white spots of kaolinite, heavy mechanical components, contains many clayes, has plastic or sticky state. The soil texture is not good, its organic matter is poor so it is less porous, squash, the thickness of litoma layer varies from $1.5-2.0 \mathrm{~m}$.

The layer of weathered bazan: This layer lies under the litoma layer, is the bazan eruption, the upper part is weathered bazan and below is original bazan. The layer of original bazan rock is mainly exposed in stream slots. The stone is gray, solid, less chapped, less capable to keep water. The bauxite mining process does not use chemical, people only take away the ore layer, so that these mine activities do not cause toxic substances in the soil environment. It mainly destroys the structure of the soil layers as mentioned above, affecting the quality of cover soil used to cover the zone which has been mined, and then trees will be planted at that zone. Therefore, this research focused on studying the quality of cover soil, especially the nutrients in soil to make the basis for the selection of suitable crops.

For the evaluation of soil quality, the study refered the soil analysis data from the Department of Science and Technology of Lam Dong province at the locations where ore was mined. The data is shown in Table 4, which whows that the mechanical composition of soil at Tan Rai Bauxite mine was mild to medium flesh soil, $\mathrm{pH}$ was slightly acidic to neutral from $5.4-6 \mathrm{pH}_{\mathrm{H} 2 \mathrm{O}} ; 6-6.8 \mathrm{pH}_{\mathrm{KCl}}$, ability to keep water was from 57.22-77.76\%. Soil samples had total $\mathrm{N}$ content ranging from poor to moderate (from 37.9$122 \mathrm{mg} / 100 \mathrm{~g}$, respectively, $0.038-0.122 \%$ ), total $\mathrm{P}$ was at rich level (from 287.1 to $492.6 \mathrm{mg} / 100 \mathrm{~g}$, respectively 0.278-0.493\%), Potassium levelwas at poor level (15.8$43.3 \mathrm{mg} / \mathrm{kg}$ ), Total nitrogen fixation micro-organism was from $2.5 \cdot 10^{2}-9 \cdot 6 \cdot 10^{5} \mathrm{CFU} / \mathrm{g}$. It can be said thatthe soil at the locations where ore was minedcontains low nutrients such as nitrogen, potassium, therefore, when planting trees to recover the mine soil after exploiting ore, it should focus on measures to improve humus content andorganic matter in the soil by reasonable means in farming and fertilizing. Besides, in the rainy season with heavy rainfall, the soil is prone to erosion, leading to the risk of cover soil degradation if not actively protected and properly used.

Table 4. The analytical results of soil samples at Tan Rai Bauxite mining area

\begin{tabular}{|c|c|c|c|c|c|c|c|c|}
\hline $\begin{array}{c}\text { Soil } \\
\text { samples }\end{array}$ & $\begin{array}{c}\text { Nitrogen } \\
\text { content } \\
\text { mg/100g }\end{array}$ & $\begin{array}{c}\text { Total } \\
\text { phosphorus } \\
\text { content, } \\
\mathrm{P}_{2} \mathrm{O}_{5}, \\
\text { mg/100g }\end{array}$ & $\begin{array}{c}\text { Potassium } \\
\text { contentK, } \\
\mathrm{mg} / \mathrm{kg} \\
\mathrm{K}_{2} \mathrm{O}\end{array}$ & $\begin{array}{c}\text { pH } \\
\text { (KCI) }\end{array}$ & $\underset{\left(\mathbf{H}_{2} \mathbf{O}\right)}{\mathbf{p H}}$ & $\begin{array}{l}\text { Mechanical } \\
\text { composition }\end{array}$ & $\begin{array}{c}\text { Water } \\
\text { holding } \\
\text { capacity } \\
\text { (water } \\
\text { absorption), } \\
\%\end{array}$ & $\begin{array}{c}\text { Total } \\
\text { number of } \\
\text { nitrogen } \\
\text { fixation, } \\
\text { CFU/g }\end{array}$ \\
\hline Sample 1 & 80,2 & 405,7 & 24,6 & 5,5 & 6,1 & Mild flesh soil & 70,21 & $2,7.10^{5}$ \\
\hline Sample 2 & 81,9 & 381,5 & 27,4 & 6 & 6,8 & Mild flesh soil & 57,22 & $7,4.10^{4}$ \\
\hline Sample 3 & 122 & 492,6 & 17,8 & 6 & 6,7 & Mild flesh soil & 60,67 & $6,9 \cdot 10^{4}$ \\
\hline Sample 4 & 84,5 & 422,1 & 43,3 & 5,9 & 6,7 & Mediumflesh soil & 68,41 & $2,0.10^{5}$ \\
\hline Sample 5 & 37,9 & 367,3 & 15,8 & 5,8 & 6,3 & Mild flesh soil & 65,24 & $2,8.10^{5}$ \\
\hline Sample 6 & 71,8 & 333,5 & 24 & 5,7 & 6 & Mild flesh soil & 77,76 & $2,5.10^{5}$ \\
\hline Sample 7 & 64,2 & 287,1 & 22,1 & 5,8 & 6,3 & Mild flesh soil & 73,39 & $2,5.10^{2}$ \\
\hline Sample 8 & 88,8 & 373,7 & 24 & 5,4 & 6,3 & Mild flesh soil & 73,39 & $8,9.10^{4}$ \\
\hline Sample 9 & 64,7 & 319,9 & 29,1 & 5,7 & 6,4 & Medium flesh soil & 73,98 & $9,6.10^{5}$ \\
\hline
\end{tabular}




\begin{tabular}{|c|c|c|c|c|c|c|c|c|}
\hline $\begin{array}{c}\text { Soil } \\
\text { samples }\end{array}$ & $\begin{array}{l}\text { Nitrogen } \\
\text { content } \\
\text { mg/100g }\end{array}$ & $\begin{array}{c}\text { Total } \\
\text { phosphorus } \\
\text { content, } \\
\mathrm{P}_{\mathbf{2}} \mathrm{O}_{5}, \\
\mathbf{m g} / \mathbf{1 0 0 g}\end{array}$ & $\begin{array}{c}\text { Potassium } \\
\text { contentK, } \\
\text { mg/kg } \\
K_{2} \mathrm{O}\end{array}$ & $\begin{array}{c}\mathbf{p H} \\
(\mathrm{KCl})\end{array}$ & $\begin{array}{c}\text { pH } \\
\left(\mathbf{H}_{2} \mathbf{O}\right)\end{array}$ & $\begin{array}{l}\text { Mechanical } \\
\text { composition }\end{array}$ & $\begin{array}{c}\text { Water } \\
\text { holding } \\
\text { capacity } \\
\text { (water } \\
\text { absorption), } \\
\%\end{array}$ & $\begin{array}{c}\text { Total } \\
\text { number of } \\
\text { nitrogen } \\
\text { fixation, } \\
\text { CFU/g }\end{array}$ \\
\hline Sample10 & 84,9 & 294,4 & 27,4 & 5,9 & 6,4 & Mild flesh soil & 71,17 & $6,7.10^{5}$ \\
\hline
\end{tabular}

Source: Center for analysis and quality certification - Lam Dong Department of Science and Technology

\section{Conclusion}

The status of the air and waste water environment in Tan Rai Bauxite mining area is generally not polluted, the surface water environment here is mainly polluted by TSS, the groundwater is being highly polluted by Coliform, the soil environment is in danger of being seriously degraded if there are no measures for the environment rehabilitation after mining. There is no vegetation cover on the surface of the post-mining site, so the possibility of dust emission, erosion and soil slide from the disposal site is very high. Moreover, waste soil is not too poor nutrition which should be improved when planting trees. The above studied environment state is very suitable for planting pine and acacia. Planting trees for green cover in mine exploiting area should be paid attention to by the investors and the local authorities.

\section{References}

[1] Vietnamese Government (2007), "The zoning partition planningfor exploration, exploitation, processing and use of bauxite ore in theperiod of 2007-2015, with a vision to $2025 "$ ".

[2] Ministry of Natural Resources and Environment (2006), Environmental Impact Assessment Report of Lam Dong Bauxite-Aluminum Complex Project (alumina plant capacity of 600,000 tons/year).

[3] Lam Dong Aluminum Company - Vinacomin (20152017), Report on theenvironmental monitoring results of Lam Dong Aluminum Company Vinacomin.

[4] Ministry of Natural Resources and Environment (2015), Report on discharge of wastewater into the water source of the Lam Dong Bauxite - Aluminum Complex Project.

[5] Vinacomin Informatics, Technology, Environment Joint Stock Company (2017), Report on environmental monitoring results of Vinacomin in Lam Dong bauxite area.

[6] Ministry of Natural Resources and Environment (2010), Additional EIA report of Lam Dong Bauxite - Aluminum Complex Project.

[7] QCVN 46:2012/BTNMT: National Technical Regulation on meterological Observations.

[8] TCVN 7878-2:2010 (ISO 1996-2:2007): Acoustic Description, measurement and assessment of environmental noise - Part 2: Determination of environmental noise levels.
[9] TCVN 5971:1995 (ISO 6767:1990): Ambient air Determination of the mass concentration of sulfur diexide Tetrachloromercurate (TCM) pararosaniline method.

[10] TCVN 6137:2009 (ISO 6768:1998): Ambient air Determination of mass concentration of nitrogen dioxide - Modified Griess-Saltzman method.

[11] TCVN 5067:1995: Air quality - Weighing method for determination of dust content.

[12] TCVN 6663-1:2011 (ISO 5667-1:2006): Water quality - Sampling - Part 1: Guidance on the design of sampling programmes and sampling techniques.

[13] TCVN 6663-3:2008 (ISO 5667-3:2003): Water quality - Sampling - Part 3: Guidance on the preservation and handling of water samples.

[14] TCVN 6663-6:2008 (ISO 5667-6:2005): Water quality - Sampling - Part 6: Guidance on sampling of rivers and streams.

[15] TCVN 5994-1995: Water quality Sampling - Part 4: Guidance on sampling from natural lakes and manmade lakes.

[16] TCVN 6492:2011 (ISO 10523:2008): Water quality - Determination of $\mathrm{pH}$.

[17] QCVN 08-MT:2015/BTNMT: National technical regulation on surface water quality.

[18] QCVN 40:2011/BTNMT - National technical regulation on industrial wastewater

[19] Brunori, C., Cremisini, C., Massanisso, P., Pinto, V., Torricelli, L. (2005) Reuse of a treated red mud bauxite waste: studies on environmental compatibility. Journal of Hazardous Materials, 117(1), 55-63.

[20] Fontanier, C., Fabri, M.-C., Buscail, R., Biscara, L., Koho, K., Reichart, G.J., Cossa, D., Galaup, S., Chabaud, G., Pigot,, L. (2012) Deep-sea foraminifera from the Cassidaigne Canyon (NW Mediterranean): Assessing the environmental impact of bauxite red mud disposal. Marine Pollution Bulletin, 64(9), 1895-1910.

[21] Wanchao Liu, Xiangqing Chen, Wangxing Li, Yanfen Yu, Kun Yan (2014) Environmental assessment, management and utilization of red mud in China. Journal of Cleaner Production, 84, 606610. 